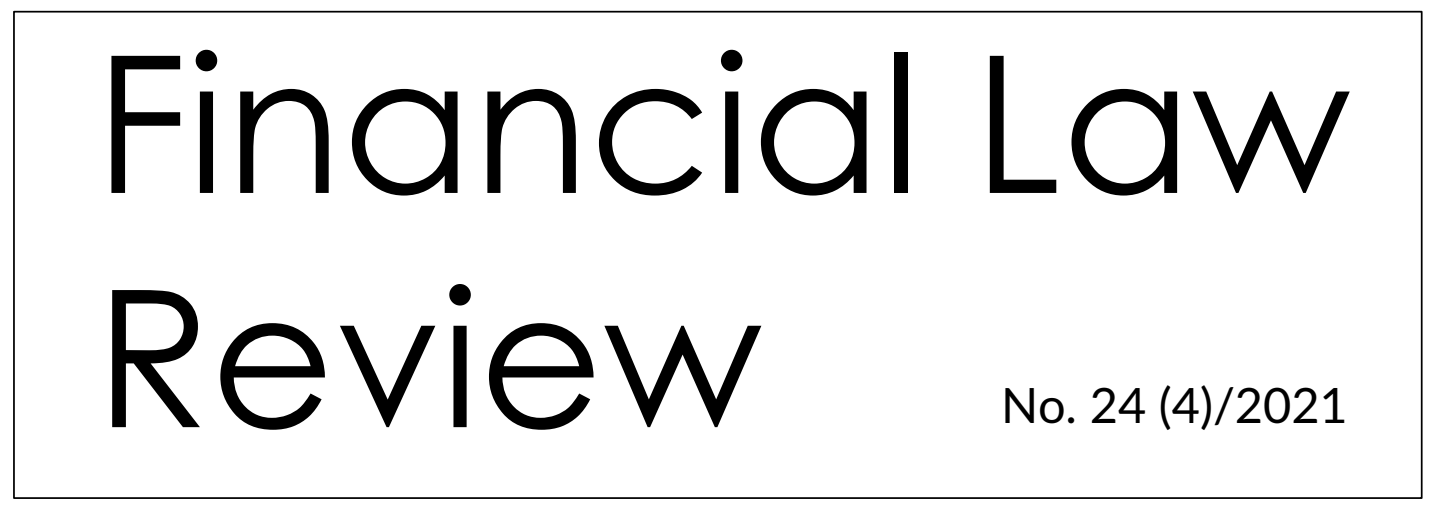

UNIVERSITY OF GDAŃSK • MASARYK UNIVERSITY • PAVEL JOZEF ŠAFÁRIK UNIVERSITY • UNIVERSITY OF VORONEZH http://www.ejournals.eu/FLR

\title{
ADAM KUCHARSKI* \\ MORAL THREATS IN FINANCES IN THE LIGHT OF CATHOLIC SOCIAL THOUGHT (SELECTED ISSUES)
}

\begin{abstract}
The impact of the importance of finance on social life, unprecedented in history, has numerous consequences. Basing the world economy on debt money may significantly change the existing ownership systems and lead to the formation of a new world power based on turbo-capitalism. These tendencies are supported by the postulate to limit the influence of ethics on economic behavior, which leads to the support of the general policy of overconsumption. The aim of this article is to highlight some of the threats resulting from the progressive financialisation of social life and the development of corpo-capitalism. Some theses from the field of Catholic social thought will serve as the background for the following reflection. The analytical-synthetic method adopted in the article consists in comparing selected moral threats present in the sphere of contemporary finances with some statements taken from documents and studies in the area of social Christian morality. This procedure aims to emphasize the need to recognize the key role of the ethical dimension of economic life as an element of the internal structure of any free, truly human behavior.
\end{abstract}

Key words: finance, ethics, Catholic social science.

JEL Classification: A12, Z1

\footnotetext{
* PhD student at the Pontifical Faculty of Theology in Wrocław,. The author is a doctor of legal sciences $(\mathrm{PhD})$ and an academic bachelor in theology. Author specializes in tax law and Catholic social science. He is the author of more than 30 articles in the field of tax law, civil law and Catholic social science.

Contact email: obywatelak2025@gmail.com; ORCID number: 0000-0001-9278-7522.
} 


\section{Introduction}

Financial and economic issues affect people both individually and socially. They have a great influence on decisions in everyday life and important life choices. In particular, modern times are characterized by a significant saturation of economic factors. This specificity of the beginning of the XXI century can also be seen in the social teaching of the Church. The purpose of this article is to recall some of the risks identified in this teaching. It is, in particular, about drawing attention to such issues as: the destructive role of unrestrained competition, the effects of disregarding sustainable economic policy, the consequences of failure to promote a human being, excessive financialization of life, the process of separating finance from the real economy, immoral financial and tax practices, or threats related to the growing process of globalization. In the light of the analysis of these problems, it becomes obvious that the economy, like any other sphere of free human activity, needs ethics in order to function properly [Benedict XVI 2009: 45] ${ }^{1}$. At stake is the genuine well-being of the majority of people who expect responsible development of the economy and finance in line with the principles of justice and the development of the common good [Watykan wydał dokument dla finansistów 2018]. Hence, it is worth considering a short analysis of the above-mentioned issues.

\section{General picture of the moral problems in the area of finance}

The starting point is undoubtedly a call to study the signs of the times and interpret them in the light of the Gospel [Second Vatican Ecumenical Council 1965: 4]. A particular challenge in this field is the enormous progress, also in the economic aspect. The intensification of the movement of financial values, the flow of goods and services, shared and virtual currencies and ubiquitous communication are a reality unprecedented in history on such a scale. Hence, confusion affecting the moral sphere, both at the level of the individual and society, may turn out to be more real than ever before. Generally speaking, it is difficult to disagree with the critical opinion of the authors of the Vatican document: "Oeconomicae et pecuniariae quaestiones. Considerations for an Ethical Discernment Regarding Some Aspects of the Present Economic-Financial System", issued by the Congregation for the Doctrine of the Faith and the Dicastery for Integral Human Development on May 17, 2018, on the moral condition of modern financial markets. This document identifies eight economic and economic areas that currently raise particular

\footnotetext{
${ }^{1}$ In the case of official Vatican documents, including papal ones, the reference in footnotes is traditionally relevant to the paragraph number.
} 
doubts, i.e.$:$ domination of capital over labor, credit speculation, manipulations of capital markets, the need for stricter regulation of financial markets, dishonesty of financial advisors, destructive corporate culture, asymmetry in contacts between clients and institutions financial institutions and the practice of non-payment of taxes, especially in tax havens [Hirsch, Osiem grzechów głównych rynków finansowych według papieża Franciszka 2018]. When analyzing the negative effects of the operation of financial markets, the following points are emphasized in particular: promoting social inequalities, environmental damage, economic insecurity and fraud. The business world is losing its positive dimension, especially in the context of speculative transactions, including those undertaken on a high frequency [Congregation for the Doctrine of the Faith and the Department for Integral Human Development 2018: 15]. The social losses caused by them include, for example, fueling speculative tendencies, loss of savings or reluctance to prudent management [Sokołowski 2016: 38]. The final horizon of the common good cannot be implemented against some social groups, in particular the most vulnerable. Hence, care for the creation and dissemination of wealth must be accompanied by responsibility and the horizon of adequate ethics [Sokołowski 2016: 8].

\section{Selected threats of morally disordered finances}

\subsection{The importance of unbridled economic competition}

Negligence in the area of finance is often caused by the social sin of greed. It is about a philosophy blindly focused on the beneficial and causative power of the free market and the unrestrained competition that prevails there. Its internal feature is the strong antagonization of society and the accumulation of capital in the hands of a small group of people and corporations. The problem is not so much the existence of differences between individual groups as their constant growth. For example, a 2014 global wealth survey shows that the world's richest 1 percent accumulated 48 percent of the world's wealth, almost as much as the remaining 99 percent of humanity, and in 2009 this proportion was still 31 percent to 69 percent [Rogacin, Jeden procent populacji ma prawie tyle pieniędzy, co... pozostałe 99 procent, 2015].

Observation of economic reality shows that economic growth without ethical goals leads to excess consumption in rich countries and a spiral of debt in poor countries. In this sense, the functioning global financial system does not work as long as it makes people dependent on it, disregarding human dignity, the social character of the economy, social justice and the good of the whole. To be healthy, competition must, inter alia, be free 
from unfair elements and be conducted in a spirit of mutual respect and justice. An element of this justice is both the functioning of the "option for the poor" and taking into account the real situation of contractors, excluding exploitation and fraud (including by the state). Hence, there can be no support for a system in which economic freedom is not framed within the legal system, putting it at the service of integral human freedom and treating it as a special dimension of this freedom, which is primarily ethical and religious in nature [John Paul II 1991: 42].

The morally disordered hegemony of market logic ultimately disturbs the balance and peace of family life and exacerbates discrimination [Synod Biskupów 2015: 91]. A socially acceptable competition mechanism must not be guided by "inhuman" logic. Likewise, profitability cannot be the only indicator of the company's health [John Paul II 1991: 35]. The necessity of profit is understandable, but the profit orientation only when it is made by blameworthy means and its ultimate end is not the common good, "it risks destroying wealth and creating poverty" [Benedict XVI 2009: 21, 29]. In this sense, profit is "a good servant, but a <<poor>> master" [Pontifical Council for Justice and Peace 2014: 56].

\subsection{Disregard for the principles of sustainable economic policy}

Income optimization cannot lead to the reification of all goods. For profit cannot be achieved at any cost [Congregation for the Doctrine of the Faith and the Department for Integral Human Development 2018: 11]. It is not justified if it does not fulfill the purpose of the integral promotion of the human person, the universal destination of goods and a preferential option for the poor [John Paul II 1987: 42]. One cannot succumb to the selfdestructive civilization of individualism. Its opposite is a balanced policy based on interpersonal communion. If we want the true welfare of mankind, "money must serve, not rule" [Francis 2013: 58]. Development cannot be based only on utility and profit, but should be fair, that is, take into account the associated responsibility [John Paul II 1991: 42]. Hence, when promoting shared prosperity, a proper vision of progress must not be neglected. Otherwise, it may turn into an ideology of market fundamentalism, converting every aspect of life only into economic goods. This mathematization of a spiritless economy is not conducive to eradicating injustice. Rather, it leads to the impoverishment of the vision of man, an unlimited increase in the production of unnecessary or even harmful goods, and then control over man and his life decisions by environments that stimulate these factors. The need for the sustainable development of mankind cannot be 
pushed to the background or completely excluded from the orbit of important interests. It is an effort to create the necessary conditions for a more integral development of a world in which "each individual can give and receive, and in which the progress of some will no longer be an obstacle to the development of others, nor a pretext for their enslavement" [Congregation for the Doctrine of the Faith 1986: 90].

The need for "ecological conversion" requires similar in-depth reflection [John Paul II 2001: 44]. The true development of the human person "presumes full respect for the human person" [Francis 2015: 5]. It should also be oriented towards the natural world and take into account the nature of each being and their interconnection into an ordered system predicted by God [John Paul II 1987: 34].

\subsection{Failure to promote the human person}

Faced with these threats, the Church calls for the promotion of the integral development of the human person in the light of the Gospel. In this sense, genuine development must foster the development of each and the whole person [Paul VI 1967: 14]. This happens, among other things, by building sincere relations between people and God and mutual relations between people themselves, and the proper management of the world's resources [Press Conference to present the new Document of the Congregation for the Doctrine of the Faith and the Dicastery 2018]. The latter also have a common reference [Francis 2015: 93]. Hence, a society in which individualism reigns inhibits the integral development of its members. It is not surprising, therefore, the growing demand for the services of psychologists and therapists and the increasingly common "burnout" syndrome [Grygiel 2019].

In this light, the provision of services must take into account not only the profit and usefulness, or even the expectations of customers, but also the truth about the goods created and the impact on the lives of themselves and other people. Some help in this matter is the awareness of the hierarchy of goods and needs [Pontifical Council for Justice and Peace 2014: 42-43]. Taking responsibility for another human being, one must be aware of the impact on his life. Work or study change people. Improper management of the company, including those that offend human dignity, weaken the sense of responsibility, or take away the ability to initiate initiative, besides the final reduction in efficiency, has a negative impact on the history of a specific person. Moral and economic conflicts of interest, for example of entities valuing assets and benefiting from their 
commercialization, cannot remain without impact on the ethical assessment of the activities of the corporations or individuals involved.

The human person has a uniquely relational nature, and the meaning of his eternal search cannot be reduced to the logic of consumption, nor to the economic aspects of life. Financial activity manifests its primary purpose in creating value through morally permissible means and favoring the dispersion of capital into the essential circulation of wealth. What is morally unacceptable is not so much income, but rather using inequality to the detriment of others, taking advantage of their economic handicap.

An important goal of businesses and trading systems is to respond to real human needs [Pontifical Council for Justice and Peace 2014: 37-38]. The company is by nature focused on others: it combines talents, talents, energy with the ability to serve the needs of others. What distinguishes a speculator from an innovator is the unbridled desire to maximize profit without considering other considerations. The latter, taking advantage of his position and accumulated economic and intellectual capital, looks for undeveloped areas where his initiative and life passion may become socially useful, which will then translate into consumer interest and a satisfactory financial result.

\subsection{Financialization of social life}

The absolute domination of finances in social life leads to economic instability aimed at achieving short-term profits and the promotion of narrowly understood individualism at the expense of building the common good. This means a shift away from the appreciation of the role of production in favor of finance, which is becoming a symbol of the modern variety of capitalism [Mroczkowski 2013: 111]. In the case of the logic of ruthless competition and the prospect of quick wealth, one can even speak of casino capitalism, where profits are privatized and losses are transferred to the entire society. It is related to the malfunctioning of part of the securities market. According to Ireneusz Mroczkowski, "Pope Francis sees the way to solve global economic problems, as well as moral problems, in actions capable of resigning from the absolute autonomy of financial speculation markets and removing the structural causes of imbalance" [Mroczkowski 2013: 115].

An interesting aspect of the discussed issues is drawing attention to the complexity level of modern financial mechanisms. Their complexity deepens the asymmetry between buyers and those who commercialize financial products. This puts into question the traditional principle of the buyer's responsibility for assessing the quality of the purchased good. This rule assumes parity in the protection of the own interests of contractors. A similar reversal 
of the order can be observed in the relationship between capital rent and labor income, where work becomes the "instrument" and money the goal [Congregation for the Doctrine of the Faith and the Department for Integral Human Development 2018: 15].

The modern world of finance has dominated other areas of the economy. The financiers' awareness of the social mortgage on any form of property should help understand the principles of universal destination of goods and solidarity. Thus, it should encourage consideration of the legitimate needs of people (taking into account their inherent dignity, predispositions and often unjust poverty), while agreeing to proportionally reward their contribution, effort and risk taken.

\subsection{Separation of finances from the service of real economy}

A sign of the times is especially the need to oppose a system that is not focused on serving the real economy [Francis 2015: 109]. This must entail a change in the financial paradigm. Markets alone cannot guarantee real progress. It is hard not to notice that the irresponsible economic system makes the strong ones even stronger, the weaker ones even weaker, which deepens social inequalities. In this way, capital, having gained new freedom, no longer needs to be accountable to the people of those countries where profits are made. Its domination is manifested, inter alia, in the trend that reduces the essence of business to maximizing shareholders' wealth, while complying with the ethical standards imposed by them [Pontifical Council for Justice and Peace 2014: 24]. In this aspect, the sources of origin of funds (the so-called characteristics of the economic portfolio) and their participation in real projects aimed both at the benefit of their owners and the common good are important.

In this light, the uncontrolled expansion of financial markets must be a serious concern. Since the 1990s, money and credit instruments grew faster than the accumulation of wealth in the economy, hence the subsequent speculative bubbles that led to crises of insolvency and confidence [Pontifical Council for Justice and Peace 2011]. The excessive amount of fiat money and the multitude of financial instruments contributed to this. Such a situation, in addition to the threat to the dignity of work, pushes the masses of the world's population to the margins, depriving them of escape routes from the situation of decisionmaking alienation as to the fate of themselves and their loved ones. This jeopardizes the initial establishment of financial activity as a form of service to the real economy. The observed condition of the financial markets seems to elude this dependence dangerously [Pontifical Council for Justice and Peace 2014: 21]. Financial activity conducted without 
taking into account the longer perspective and the participation of entire social groups in it, loses the role of a bridge between the present and the future and a catalyst for new jobs and production opportunities, including innovative production.

In the modern world, there is a far-reaching incoherence between the production sector and the financial sector [Fleischer 2014: 293]. On the over-the-counter market, derivative trading is 10 times larger than the real world economy, while the foreign exchange market is 15 times larger. As a result, in 2006, the financial sector in the US "grabbed" $1 / 3$ of all corporate profits, while the share of this sector in generating GDP is 4\% [Fleischer 2014: 294].

It inevitably brings to mind a warning against the power of a handful of managers over enterprises participating in real production [Pius XI 1931: 105-106]. Pius XI has already pointed out that, in addition to the accumulation of wealth, the problem is immense power and despotic economic dictatorship is consolidated in the hands of a few, who often are not owners but only the trustees and managing directors of invested funds which they administer according to their own arbitrary will and pleasure. This dictatorship is being most forcibly exercised by those who, since they hold the money and completely control it, control credit also and rule the lending of money. Hence they regulate the flow, so to speak, of the life-blood whereby the entire economic system lives, and have so firmly in their grasp the soul, as it were, of economic life that no one can breathe against their will" [Pius XI 1931: 105-106].

Neoliberalism leads to the mathematization and converting into the money issue of almost everything, because, according to this doctrine, you can trade and anything that can be profitable, including expectations [Kołotko 2010: 121]. The domination of the financial system over the real economy reverses the natural order of things and the relationship between material and virtual goods. This leads to disastrous consequences in the form of a significant impoverishment of millions of people, and enormous wealth of the few who take advantage of the possibility of unlimited creation of virtual money. For example, according to Krzysztof Rybiński, the total amount of derivatives, created by the financial system and sold on financial markets, exceeds 10 times the global value of bank deposits [Rybiński 2008: 35-37].

Profiting from trading financial assets, such as stocks, without being reflected in their real value based on the actual economic position of the enterprise, is usually part of speculative activities. This aspect of currency trading is particularly dangerous if it takes on 
a systemic nature, leading to a disconnection of the direction of the flow of world finances from economic activities that build the common good.

\subsection{The risk of unreflective indebtedness}

In the context of the flood of offers in Western culture, Pope Francis, apart from calling to open hearts to the needy in poor countries, also calls for stopping the process of unreasonable indebtedness of societies living in affluence. This is especially true of people who therefore lose their financial liquidity and are on the verge of bankruptcy. You cannot live on credit indefinitely. The accumulation of deficits and debts is a burden on investing in the future, and in the global system it places an "unbearable burden" on the shoulders of the young generation. Hence, the Pope calls for education and a sober lifestyle that allows to distinguish what is superfluous from what is necessary [Address of His Holiness Pope Francis to the members of the National Council of the Anti-Usury Foundation 2018]. In his opinion, abuses can be prevented: "by educating them to a modest lifestyle that can distinguish between what is superfluous and what is necessary, and which teaches responsibility not to take out loans to buy things that can be given up. It is important that we rehabilitate the virtues of poverty and self-sacrifice. Poverty, so as not to become a slave to things, and self-sacrifice, because you can't have everything in life. It is important to develop an integrity and integrity mentality, both in individuals and in institutions" [Pope on the fight against usury and gambling 2018].

The consumer boom caused a change in the social mentality: the attitude of saving in order to buy some good with cash was replaced by the orientation "buy now pay later" [LewickaStrzałecka 2010: 218]. There is an urgent need to reorient this optics, which is now shaping the generation of impatient hedonists, deprived of the inner strength of abstinence. The latter is necessary for practicing a virtuous life. The key to the environment stimulating the practice of overconsumption is to develop the habit of quickly satisfying whims, which provides an effective means of socio-political control.

An economy where everything is subject to play and competition, contributing to the deepening of social inequalities, contributes to the recognition of man as a kind of consumer good. Such a culture of prosperity deprives us of sensitivity and peace, if the market, upon request, does not immediately offer new products that meet imaginary expectations. At the root of this situation is an anthropological crisis that denies the primacy of the human person over the thing [Francis 2013: 55]. 
In the economic field, respect for human dignity requires the practice of the virtue of moderation in order to control attachment to the goods of this world, the virtue of justice to secure the rights of one's neighbor and give him what is due to him, and the virtue of solidarity [Catechism of the Catholic Church 1993: 2407]. This is impossible in an economy without a human purpose, where the tyranny of debt is accepted and man is reduced to just one of his needs: consumption [Francis 2013: 55-56].

\subsection{Immoral practices of financial advisers}

Another issue is the immoral behavior of financial agents. Negative selection of people can already be noted in some business schools. The morally questionable activities of financial advisors in the field of savings management include, but are not limited to: excessive movement of the investment portfolio aimed at increasing commission income for a bank or other financial intermediary; lack of impartiality in offering savings instruments that, compared to products of other banks, meet the needs of customers to a lesser extent; negligence on the part of financial advisors of the related interests of their clients [Congregation for the Doctrine of the Faith and the Department for Integral Human Development 2018: 22]. The ethical inefficiency of the current financial system makes it necessary to change the way it is run. In the first place, this change has to affect people involved in the economy, and it is always costly and difficult [Press Conference to present the new Document of the Congregation for the Doctrine of the Faith and the Dicastery 2018].

From the mid-1970s, the financial sphere became superior to the economic sphere, and money turnover became a victim of moral hazard. This turnover, or more precisely, financial speculation, turned out to be more important than production, which we have never dealt with before. Banks, which were to serve the economy, became quasienterprises, whose interests, unfortunately, did not always correspond to the interests of society, because money borrowed outside the economy, or even against it, blindly stimulates the economy or even leads to its slowdown [Krukowska 2012].

The Appointment of the Business Leader document emphasizes the importance of the entrepreneurial vocation as a genuine human and Christian call to develop production and offer services to customers and communities through an adequate form of market economy [Pontifical Council for Justice and Peace 2014: 5-6]. At the same time, it points to the special danger associated with the so-called a "divided" life where there is a gap between the faith we profess and mortality. Importantly, the Second Vatican Council 
classified this split as the more serious irregularities of our time. [Second Vatican Ecumenical Council 1965: 43]. Only those who sincerely strive for internal integration are capable of accepting the truth about their vocation and responding properly to this divine call. In its light, participation, and especially leadership in business (including financial leadership), appears in terms of service (to God, family, work environment, society). This approach distinguishes Christian directors and the work environment that such people seek to develop [Pontifical Council for Justice and Peace 2014: 5-6]. A good trader: "He thinks first about service and then about profit, ... he employs workers to produce goods of real value, does not mislead them by demanding participation in the creation of something futile, and even harmful or evil; it offers consumers only useful goods and services, rather than taking advantage of their inexperience and weakness, by tricking them into spending their money on something they do not need and which is not only useless, even harmful" [Nell-Breuning 1936: 115-116].

In a situation where the average American public company 75 percent. stock options go into the hands of a few top executives who have a strong incentive to raise stock prices in the short term. They are also held hostage by investors who agree to high salaries of managers, who bring them short-term but high profits" [Krukowska 2017].

It is worth noting that for Joseph Butler, the calculus of probability has become a life guide [Brenner 2016: 59]. Gambling promotes usury and creates a favorable environment for it. The latter, in the form of exploitation of gambling victims, tramples human dignity, becoming a driving force of corruption and an obstacle to the common good.

The shift in economic doctrine from Keynesism to neoliberalism and the collapse of the Soviet Union lead to the expansion of wealthy Western countries, leading to today's globalization. The service sector is developing (previously industry has replaced agriculture). Shock therapy is used in developing countries. According to Ricardo's theory, the USA has specialized in the field that gave it its greatest comparative advantage - in capital trading. But in times of crisis, the presidents who exterminated the state want it to help.

\subsection{Particular threats of globalization}

Nowadays, the "tool" in the form of financial markets, usurping moral autonomy, has become an end instead of a means. An example of this may be an attempt to solve, for example, the fertility crisis an increase in consumption on credit; or the problem of overproduction irresponsible creation of money and the creation of credit bubbles. 
Observing the related threats, Pope Benedict XVI aptly noted that "as society becomes ever more globalized, it makes us neighbours but does not make us brothers" [Benedict XVI 2009: 19].

Today, capital has become extremely mobile. It is possible to earn much more and faster in the money and foreign exchange markets than by investing in the "real economy" - in the production of goods and services [Schasching 1997: 91]. The process of displacing the actual exchange of goods and services from the areopagus of the economy by financial markets, focused on the abstract multiplication of money, i.e. the domination of the socalled "casino capitalism" with its spiral of debt poses a problem for itself [Dylus 1998].

Pope Paul VI, in his Encyclical Populorum Progressio, pointed out that full and global development is a special dimension of peace [Paul VI 1967: 76-77]. The importance of this observation was recognized forty years later, when in its 2007 report, the International Monetary Fund saw a close link between an improperly managed process of globalization and the great inequalities of the world [Pontifical Council for Justice and Peace 2011]. For the economy to function properly, it needs ethics, and not only of any kind, but one that is friendly to people [Benedict XVI 2009: 45]. Technique is unable to solve many human problems, and its absolutization tends to produce the inability to perceive what cannot be explained by ordinary matter [Benedict XVI 2009: 77]. The technical and economic opportunities brought about by the process of globalization should be used for the true development of humanity, based on mutual respect and the foundation of the inalienable dignity of man as a child of God.

The possibility of manipulating and speculating on finances related to the functioning of the global village should be limited as much as possible. It is not appropriate that today's polycentric development means that "the world's wealth is growing in absolute terms, but inequalities are on the increase" [Benedict XVI 2009: 22], leading to the marginalization of people who are considered "useless" according to the profitability criteria of companies [Papież krytykuje kapitalizm i przywołuje słowa Jana Pawła II 2018].

Depriving a society of rudiments of proper behavior leads to an increase in radical behavior. Stefan J. Adamski points out that the destruction of feudal structures by the industrial revolution and "wolf capitalism" led to the popularity of the Marxist idea. Thus, it warns against the effects of the growing - as a result of the current form of capitalism - the number of "rejected and unnecessary". At the beginning of the 20th century, a group of such people in Russia called superfluous became the driving force of the Bolshevik revolution [Adamski 2004]. 
The role of properly functioning financial systems is, inter alia, to ensure that the poor and their families have access to favorable forms of credit on fair terms [John Paul II 1998]. Unfortunately, today we sometimes talk about the "genocidal" action of the world's financiers, emphasizing the tragic effects of the selfish control of economic processes in a world where, among other things, as a result of globalization, the ambitions and actions of a small group may significantly contribute to world injustice [Zwoliński 2008: 52].

The fundamental problem of the modern economy is its far-reaching financialisation. It is based on the marriage of globalization and the impact of financial instruments. The latter is based on the ease of creating fiat money, the next tranche of which on the currency market can significantly change the value of any area of the real economy. With the change of the form of capitalism, banks, investors and the stock market take the floor, and the role of enterprises diminishes [Fleischer 2014: 144].

Hence, a call is heard in the world to give up the absolute autonomy of markets and financial speculation [Francis 2013: 202] and to remove the structural causes of the malfunctioning of the world economy [Benedict XVI 2007: 73]. Ultimately, it is the dignity of every human being and the common good that should shape economic policy, in including in the context of modern finance [Francis 2013: 203].

\subsection{Tax Immorality}

Another detailed issue is offshore finance and the so-called tax havens. In both cases, the immorality of the activities of the entities using them is emphasized, consisting in shifting onto the shoulders of the rest of society the financial burdens related to the creation of the common good. This exacerbates social inequalities by violating the rules of a healthy market economy, for example through the "transfer of profits to tax havens", with the simultaneous "artificial cost accounting" in countries with higher taxation. It is particularly reprehensible to launder dirty money from crime, which in fact entails co-responsibility for the human harm related to it. The offshore finance system deepens the indebtedness of less developed countries, deprived, for example, of their public levies. Meanwhile, many of these countries, when paying off interest on their debts, must significantly reduce the financing of the internal market [Congregation for the Doctrine of the Faith and the Department for Integral Human Development 2018: 31].

Any kind of appropriation and unjust retention of the good of another person, even if it is not contrary to the provisions of civil law, is against the seventh commandment. This applies to: deliberate retention of borrowed or found items, fraud in trade, payment of 
unfair wages, increasing prices using ignorance or the need of another person. Moreover it concerns also "speculation in which one contrives to manipulate the price of goods artificially in order to gain an advantage to the detriment of others; corruption in which one influences the judgment of those who must make decisions according to law; appropriation and use for private purposes of the common goods of an enterprise; work poorly done; tax evasion; forgery of checks and invoices; excessive expenses and waste" [Catechism of the Catholic Church 1993: 2409].

It is worth noting at this point the postulate of a tax on financial transactions on the international forum [Kościół wobec kryzysu finansowego 2012: 1-2]. It results, inter alia, from the fact that the participation of those responsible for the crisis in bearing its burdens is a matter of international justice. Meanwhile, in Europe so far, citizens are paying a high price for the crisis. The tax revenues were used to save the banks and finance economic support programs.

\subsection{Political effects of uncontrolled economic influence}

Deregulated finances are one of the most serious threats of our time. Without proper supervision by political authorities, in addition to the source of conflict, they can be a convenient (impersonal) tool of pressure and pressure on representatives of civil society. Hence the urgent need for stricter regulation of the financial markets. The latter cannot govern themselves. There is a need to promote transparency with regard to everything traded and to eliminate manifestations of injustice [Congregation for the Doctrine of the Faith and the Department for Integral Human Development 2018: 21].

The activity of "empty" buying and selling currency does not, in principle, produce any social good. A harmful speculative stance is characterized by "seeking quick, extraordinary profits and is primarily related to the struggle for control over existing resources. (...) Persons representing such an attitude (...) in instability may look for a source of additional benefits, as the volatility of economic conditions facilitates speculative activity" [Pietrucha 2005: 180].

Speaking about practical examples of speculative activities, Krzysztof Kietliński gives the example of Georg Soros, a global speculator on the currency markets, who - according to this author - can threaten the financial stability of even large countries at any time. In the opinion of Krzysztof Kietliński, Soros, speculating with the currency in 1992, "in a few days led to a decline in the value of the British pound by $25 \%$, and within three years (1992- 
1995) by speculating on the Italian market to a decline in the lira by $30 \% "$ [Kietliński 2006 : 162].

The lack of sufficient supervision of the banking system exposes citizens to the risk of losing property, businesses and, above all, dignity [Papież o walce z lichwą i hazardem 2018]. It is also a threat to individual countries and their civil societies. States heavily dependent on the decisions that are made at the tables of their creditors can hardly be called fully sovereign. Likewise, financial institutions operating within them are "too big to fail" as a consequence of their mistakes. In both cases, the weakness of the state and democracy is manifested. In this way, the risk of expansion of financial groups that are due to their international importance and formal location of the headquarters - outside the jurisdiction of a given state is strengthened.

Hence, according to Stefan J. Adamski, the new face of the most effective system of modern economics is a kind of marriage of "corporate capitalism" with "casino capitalism" [Adamski 2004].

According to prof. Ettore Gotti Tedeschi "an economy separated from ethics, equipped with moral independence, has found itself in the hands of people who transform its mechanisms into an instrument of power, including political power" [Kościół wobec kryzysu finansowego 2012: 1-2]. In this light, the loss of control over the creation of debts translates into the management of the labor market, and then over the entire economy ${ }^{2}$. The literature even mentions the "virus of democracy" taking over the economy where greed becomes a virtue and hypocrisy becomes the principle of business [Zwoliński 2008: $52]$.

\section{Conclusions}

The moral threats presented above in the area of financial and economic markets cannot be treated as elements outside the context of social life. The superficiality of the contemporary approach to life along with the promotion of hedonism and the "logic of success" also affects this sphere. Undoubtedly, this means the need to redefine development so that it is not only understood as "constant economic growth". The right

\footnotetext{
2 Outside the scope of this article, in principle, there is the issue of systemic considerations on the creation and functioning of public debt and the ethical effects of a specific state monetary policy. In this context, it is worth noting, for example, that "the social aspect of money morality is connected with the state's obligation to provide citizens with money of relatively constant value. Money changing its value suddenly and often causes enormous social losses, especially by eroding trust in any exchange.
} 
perspective should assume integral development. It must concern both interpersonal relations, the institutional sphere, and social financial structures.

In the first area, it is emphasized that the view of economic efficiency should be supplemented with an element of "gift logic" and selflessness [Wysocki 2010: 283]. The basic causes of underdevelopment are not so much of a "technical" nature as they result from a lack of fraternity among people. The latter entails giving up hedonism and away from understanding the market as a means of dominating others [Kościół wobec kryzysu finansowego 2012: 1-2]. This corresponds to the need to disseminate and develop among people professionally dealing with finances the basic rules of work spirituality [John Paul II 1981: 24]. This optics, based on accepting God's calling and then patiently realizing it, requires concentration and time, which finances always seem to be lacking. In this context, celebrating the Lord's Day, praying or practicing silence should not be treated as optional activities, but as part of an integrated life related to professional duties (including financial ones) [Pontifical Council for Justice and Peace 2014: 67-70].

In terms of the institutional sphere, there is a need for a mechanism of real political supervision in the sphere of managing globalization, which would respect the principles of subsidiarity and solidarity [Benedict XVI 2009: 67]. For international organizations must ensure that individual countries are not subjected to oppressive lending systems which, far from promoting progress, expose people to mechanisms that generate poverty and addiction. Hence, the idea of extraordinary power concentrated in the hands of a few, which would dominate all nations using the weakest, should be replaced with a concept understood primarily as moral strength, the ability to act in accordance with reason and therefore based on participation, limited by the scope of competence and law [Benedict XVI 2012].

In terms of financial structures, the system should aim to foster real development. A special solution in this area is the practice of microfinance, referring to the medieval institution of pious banks and the initiative of the so-called civil economy. The optics embedded in them are based on treating profit as a tool to achieve the goal, including the humanization of the market and society [Benedict XVI 2009: 45]. This deepens integration and tightens small economic relations.

The problems of financial markets presented above reveal an anthropological error underlying the causes of the global crisis. It consists in losing the understanding of who a person is and abandoning the real criterion of social projects, which is serving his real development. A false vision of the human person suggests false solutions to social issues, 
including financial ones [Kościół wobec kryzysu finansowego 2012: 1-2]. In this sense, the commitment to the humanization of modern finances is a special form of exercising mercy, implemented within the framework of macroeconomics, where building a civilization of love linked to truth is the key to genuine development based on solid moral foundations. 


\section{References}

Brenner R., Dążenie do szczęścia: jak usuwać, a nie stwarzać bariery, w: Człowiek w gospodarce. Warunki rozwoju. Wybrane zagadnienia, red. E. Kowalewska, A. Wincewicz-Price [E. Kowalewska, A. Wincewicz-Price (eds.), Striving for happiness: how to remove, and not create a barrier, in: Man in the economy. Development conditions. Selected Issues], Warszawa: Centrum Myśli Jana Pawła II - Fundacja Konrada Adenauera [John Paul II Centre of Thought - Foundation of Conrad Adenauer], 2016

Fleischer M., Kapitalizm niestety nie( )ludzki [Unfortunately, capitalism is not( )human], Kraków: Libron 2014

John Paul II, Catechesis (January 17, 2001), L'Osservatore Romano no. 4, 2001

K. Kietliński, Moralna ocena procentów, odsetek i lichwy w działalności finansowej [Moral evaluation of interest, interest and usury in financial activity], w: [in:] B. Polszakiewicz, J. Boehlke (eds.), Ład instytucjonalny w gospodarce [Institutional order in the economy], vol. II, Toruń 2006

Kołotko G., Neoliberalizm a światowy kryzys ekonomiczny [Neoliberalism and the world economic crisis], Ekonomista [Economist] nr 1, 2010

Kościół wobec kryzysu finansowego [The Church in the face of the financial crisis], Biuletyn Liderów i Asystentów Ruchów i Stowarzyszeń Katolickich [Bulletin of Catholic Movements and Associations Leaders and Assistants], no. 24, Warszawa, 2012

Lewicka-Strzałecka A., Etyczne aspekty instytucji kredytu [Ethical aspects of the credit institution], Annales: etyka w życiu gospodarczym [Annales: Ethics in Economic Life], nr 1 (vol. 13), 2010,

Mroczkowski I., Chrześcijański lider biznesu [Christian business leader], Studia Nauk Teologicznych [Studies in Theological Sciences], vol. 8, 2013

Nell-Breuning, O., Reorganization of Social Economy, Milwaukee: The Bruce Publishing Company 1936

Pietrucha J., Instytucje nieformalne porządku pieniężnego [Informal institutions of the monetary order], w: [in:] S. Patrycki, (ed.), Religia a gospodarka [Religion and the economy], vol. I, Lublin: Wydawnictwo Katolickiego Uniwersytetu Lubelskiego [Catholic University of Lublin Publishing House] 2005

Rybiński K., Liderom świata brakuje wizji [World leaders lack Vision], Kwartalnik Nauk o Przedsiębiorstwie [The Business Sciences Quarterly], nr 3, 2008

Schasching J., Wskazania nauki społecznej Kościoła na okres przemian systemowych - od kolektywizmu do gospodarki rynkowej [Indications of the social teaching of the Church for the period of systemic changes - from collectivism to the market economy], w: [in]: $\mathrm{K}$. Jaśkiewicz (red.), Katolicyzm społeczny a Polska współczesna [Social Catholicism and Contemporary Poland], Warszawa: Wydawnictwo Sióstr Loretanek [Loretto Sisters Publishing House] 1997

Sokołowski, P., Lichwa wykorzystuje przymusowe położenie człowieka. Rozmowa z Marcinem Śnieżkiem [Usury takes advantage of the compulsory situation of man. An interview with Marcin Śnieżek], Exorcysta [Exorcist], nr 4 [44], 2016

Wysocki, A., Bezinteresowność jako nowa zasada społeczna [Selflessness as a new social principle], Warszawa: Warszawskie Studia Teologiczne [Warsaw Theological Studies], No 2, 2010

Zwoliński A., Siedem grzechów głównych. Chciwość, [Seven main sins. Greed], Radom: POLWEN Polskie Wydawnictwo Encyklopedyczne: [POLWEN Polish Economic Publishing] 2008

\section{Other Official Documents}

Benedict XVI, Address to the Diplomatic Corps (8 January 2007): Acta Apostolicae Sedis 99 (2007) Benedict XVI, Encyclical Letter Caritas in veritate, (29.06.2009), Acta Apostolicae Sedis 101 (2009) Catechism of the Catholic Church, Libreria Editrice Vaticana, Citta del Vaticano 1993

Congregation for the Doctrine of the Faith, Instruction on Christian freedom and liberation, Libertatis Conscientia, (22.03.1986), Acta Apostolicae Sedis 79 (1987)

Congregation for the Doctrine of the Faith and the Department for Integral Human Development, Oeconomicae et pecuniariae quaestiones. Considerations for an ethical discernment regarding some aspects of the present economic-financial system, (17.05.2018)

Available at:

https://press.vatican.va/content/salastampa/en/bollettino/pubblico/2018/05/17/180517a.

html, accessed: $9^{\text {th }}$ March 2021 
Francis, Encyclical Letter Laudato si (24.05.2015), Acta Apostolicae Sedis 107 (2015)

Francis, Post-Synodal Apostolic Exhortation, Evangelii gaudium, (24.11.2013), Acta Apostolicae Sedis 105 (2013)

John Paul II, Encyclical Letter Centesimmus annus, (1.05.1991), Acta Apostolicae Sedis 83 (1991)

John Paul II, Encyclical Letter Sollecitudo rei socialis, (30.12.1987), Acta Apostolicae Sedis 80 (1988)

Paul VI, Encyclical Letter Populorum Progressio, (26.03.1967), Acta Apostolicae Sedis 59 (1967)

Pius XI, Encyclical Letter Quadragesimo Anno, (15 maja 1931), Acta Apostolicae Sedis 23 (1931)

Pontifical Council for Justice and Peace, Vocation of the business leader. A reflection, Rome 2014

Pontifical Council for Justice and Peace, Towards reforming the international financial and monetary systems in the context of global public authority, (24.10.2011)

Available at:

http://www.vatican.va/roman_curia/pontifical_councils/justpeace/documents/rc_pc_justpea cedoc_20111024_nota_en.html, accessed: $9^{\text {th }}$ March 2021

Second Vatican Ecumenical Council, Pastoral Constitution Gaudium et Spes (07.12.1965), Acta Apostolicae Sedis 58 (1966)

Synod Biskupów. XIV Zwyczajne Zgromadzenie Ogólne [Synod of Bishops. XIV Ordinary General Assembly], Relacja końcowa Synodu Biskupów dla Ojca Św. Franciszka [Final Report of the Synod of Bishops for the Holy Father Francis], (24.10.2015)

Available at:

http://www.bobolanum.edu.pl/images/wykladowcy/filipowicz/Synod_Relacja_Koncowa_pdf, accessed: $9^{\text {th }}$ March 2021

\section{Internet Resources}

Adamski S. J., Turbokapitalizm - szanse i zagrożenia [Turbocapitalism - Opportunities and Threats] (2004)

Available at:

https://portal.tezeusz.pl/2004/11/27/turbokapitalizm-szanse-i-zagrozenia/, accessed: $9^{\text {th }}$ March 2021.

Address of His Holiness Pope Francis to the members of the National Council of the Anti-Usury Foundation (03.02.2018),

Available at:

http://www.vatican.va/content/francesco/en/speeches/2018/february/documents/papafrancesco_20180203_consulta-antiusura.html, accessed: 9th March 2021.

Benedict XVI, Przemówienie do uczestników Zgromadzenia Plenarnego Papieskiej Rady "lustitia et Pax" [Address to the participants of the Plenary Assembly of the Pontifical Council "lustitia et Pax "] (03.12.2012),

Available at:

https://opoka.org.pl/biblioteka/W/WP/benedykt_xvi/przemowienia/iustitia_03122012.html, accessed: $9^{\text {th }}$ March 2021

Dylus A., Chrześcijanin na areopagu gospodarki [A Christian in the Areopagus of the Economy] (1998),

Available at:

https://opoka.org.pl/biblioteka/I/IK/chrzescijanin_gospodarka.html, accessed: $9^{\text {th }}$ March 2021

Grygiel, B., Wypalenie zawodowe na liście WHO. Co oznacza i które zawody są nim zagrożone [Burnout on the WHO list. What it means and which professions are at risk], (2019)

Available at:

https://www.focus.pl/artykul/wypalenie-zawodowe-zostalo-uznane-przez-who-trafilo-doklasyfikacji-icd-190529121308, accessed: $9^{\text {th }}$ March 2021

Hirsch, R., Osiem grzechów głównych rynków finansowych według papieża Franciszka [Eight sins of the main financial markets according to Pope Francis] (2018)

Available at:

https://next.gazeta.pl/next/7,156830,23434098,osiem-grzechow-glownych-rynkowfinansowych-wedlug-papieza-franciszka.html, accessed: $9^{\text {th }}$ March 2021

John Paul II, Message of His Holiness Pope John Paul II for the celebration of The World Day of Peace 1 January 1998

Available at: 
http://www.vatican.va/content/john-paul-ii/en/messages/peace/documents/hf_jpii_mes_08121997_xxxi-world-day-for-peace.html, accessed: $9^{\text {th }}$ March 2021

Krukowska M., Bardzo świadomie o kapitalizmie [Very consciously about capitalism] (2017) Available at:

https://forsal.pl/artykuly/1087111,bardzo-swiadomie-o-kapitalizmie.html, accessed: 9th March 2021

Krukowska M., Wyjście z pętli. [Exit the loop], Etyka w biznesie, Dodatek do Newsweek [Business ethics, Supplement to Newsweek] (z 22.10.2012)

Available at:

https://www.newsweek.pl/etyka-a-pianiadze-pawel-kozlowski-z-polskiej-akademiinauk/j24q s7b, accessed: $9^{\text {th }}$ March 2021

Papież krytykuje kapitalizm i przywołuje słowa Jana Pawła II [The Pope criticizes capitalism and recalls the words of John Paul II] (2018)

Available at:

https://deon.pl/kosciol/serwis-papieski/papiez-krytykuje-kapitalizm-i-przywoluje-slowa-janapawla-ii,423659, accessed: $9^{\text {th }}$ March 2021

Papież o walce $z$ lichwą i hazardem [Pope on the fight against usury and gambling] (03.02.2018),

Available at:

https://papiez.wiara.pl/doc/4489730.Papiez-o-walce-z-lichwa-i-hazardem, accessed: $9^{\text {th }}$ March 2021

Press Conference to present the new Document of the Congregation for the Doctrine of the Faith and the Dicastery for Promoting Integral Human Development, entitled "'Oeconomicae et pecuniariae quaestiones'. Considerations for an ethical discernment regarding some aspects of the present economic-financial system" (2018)

Available at:

https://press.vatican.va/content/salastampa/en/bollettino/pubblico/2018/05/17/180517e. html, accessed: $9^{\text {th }}$ March 2021

Rogacin, W., Jeden procent populacji ma prawie tyle pieniędzy, co... pozostałe 99 procent [One percent of the population has almost as much money as ... the remaining 99 percent] (2015) Available at: https://polskatimes.pl/jeden-procent-populacji-ma-prawie-tyle-pieniedzy-co-pozostale-99procent/ar/3720682, accessed: $9^{\text {th }}$ March 2021

Watykan wydał dokument dla finansistów [The Vatican has issued a document for financiers] (2018) Available at: https://stacja7.pl/zwatykanu/watykan-wydal-dokument-dla-finansistow, accessed: $9^{\text {th }}$ March 2021 